\title{
MODEL KOOPERATIF DENGAN BANTUAN MM DALAM PEMBELAJARAN IPA DI PROGRAM STUDI PGSD
}

\author{
Yeni Puji Astuti \\ STKIP PGRI Sumenep \\ Email:yenipuji@stkippgrisumenep.ac.id
}

\begin{abstract}
Abstrak
Di era revolusi industri 4.0, pembelajaran IPA di Perpendidikan Tinggi khususnya di Prodi Pendidikan Guru Sekolah Dasar harus diterapkan secara aktif, agar menghasilkan lulusan yang mempunyai kemampuan dan keterampilan yang tinggi. Salah satu cara dengan menerapkan model pembelajaran kooperatif berbantuan Modul Mahasiswa (MM). Model pembelajaran ini cocok diterapkan di Perpendidikan Tinggi karena mengutamakan kerja kelompok, selain itu dapat melatih keterampilan mahasiswa dalam mengemukakan pendapat dari hasil diskusi kelompok. Dengan bantuan MM, mahasiswa dapat mengerjakan tugas dalam perkuliahan lebih terstruktur, sehingga materi yang cakupannya luas dapat terselesaikan dengan tuntas dan tepat waktu.
\end{abstract}

Kata Kunci: Model Kooperatif, Modul Mahasiswa, Pembelajaran IPA

\begin{abstract}
In the era of industrial revolution 4.0, science learning in Higher Education especially in Elementary School Teacher Education Study Programs must be actively applied, in order to produce graduates who have high abilities and skills. One way is to apply a cooperative learning model assisted by the Student Module (MM). This learning model is suitable to be applied in Higher Education because it prioritizes group work, besides it can train student skills in expressing opinions from the results of group discussions. With the help of MM, students can do assignments in more structured lectures, so that material with a broad scope can be completed thoroughly and on time.
\end{abstract}

Keywords: Cooperative Model, Student Module, Science Learning

\section{Peendahuluan}

Pembelajaran di Perpendidikan Tinggi khususnya di Prodi Pendidikan Guru Sekolah Dasar harus mampu menghasilkan mahasiswa yang memiliki kemampuan dan keterampilan yang tinggi untuk menghadapi tantangan di era revolusi industri 4.0. Salah satu cara untuk menghasilkan lulusan yang mempunyai kemampuan dan keterampilan yang baik yaitu dengan memperbaiki sistem pembelajaran. Pembelajaran di Perguruan Tinggi khususnya Program Studi Pendidikan Guru Sekolah Dasar harus berpusat pada siswa agar menghasilkan mahasiswa yang memiliki keterampilan baik.
Lulusan Program Studi Pendidikan Guru Sekolah Dasar akan menghasilkan tenaga pendidik yang mengajar di Sekolah Dasar, sehingga dosen dalam menyajikan materi perkuliahan harus mampu menerapkan model, strategi, dan metode pembelajaran yang bervariasi agar tidak monoton. Penggunaan model, strategi, dan metode pembelajaran harus disesuaikan dengan materi perkuliahan. Salah satu contoh model yang tetap eksis digunakan dalam era revolusi industri ini adalah model kooperatif.

Pembelajaran kooperatif adalah suatu model pembelajaran dimana sistem belajar dan bekerja dalam kelompok-kelompok 
Yeni Puji Astuti

kecil yang berjumlah 4-6 orang secara kolaboratif sehingga dapat merangsang peserta didik lebih bergairah dalam belajar (Isjoni, 2007: 15). Sedangkan menurut Kardi \& Nur (2000) menyatakan bahwa "belajar kooperatif sangat efektif untuk memperbaiki hubungan antar suku dan etnis dalam kelas multibudaya dan memperbaiki hubungan antar peserta didik dan peserta didik penyandang cacat".

Suprijono, A (2009) menyatakan bahwa "pembelajaran kooperatif adalah konsep yang lebih luas meliputi semua jenis kerja kelompok termasuk bentuk-bentuk yang lebih dipimpin diarahkan oleh pendidik". Penerapan model kooperatif di Perguruan Tinggi, agar tidak berpusat pada Dosen maka dalam pelaksanaan pembelajaran bisa digabung dengan bantuan Modul Mahasiswa. Modul mahasiswa ini merupakan rancangan tugas yang harus dikerjakan secara berkelompok, sehingga pada fase membimbing kelompok bekerja dan belajar pendidik tidak kerepotan karena tugas yang diberikan sudah tersedia secara sistematis di MM.

Pembelajaran tentang konsep IImu Pengetahuan Alam di Perguruan Tinggi tidak hanya menekankan pada aspek kognitif saja, tetapi keterampilan harus juga diutamakan. Misalnya pada materi IPA yang cakupannya luas bisa menggunakan model kooperatif digabung dengan $\mathrm{MM}$, sehingga mampu menciptakan pembelajaran yang efektik dan efisien dari segi waktu.

\section{Pembahasan}

\section{Ciri-ciri Model Kooperatif}

Model kooperatif merupakan model yang mengutamakan kerja kelompok. Menurut Suyatno \& Asep Jihat (2002), menyatakan bahwa "ciri-ciri model kooperatif adalah sebagai berikut: 1) bertujuan untuk menuntaskan materi yang dipelajari, dengan cara peserta didik belajar dalam kelompok kooperatif; 2) kelompok yang dibentuk terdiri dari peserta didik yang memiliki kemampuan tinggi, sedang, dan rendah; 3) jika dalam kelas terdapat peserta didik yang terdiri dari beberapa ras, suku, budaya, jenis kelamin yang berbeda, maka diupayakan agar dalam tiap kelompok terdiri dari ras, suku, budaya, jenis kelamin yang berbeda pula; 4) penghargaan atas keberhasilan belajar lebih diutamakan pada kerja kelompok daripada perorangan".

\section{Tujuan Model Kooperatif}

Tujuan pokok belajar kooperatif adalah memaksimalkan belajar siswa untuk peningkatan prestasi akademik dan pemahaman baik secara individu maupun secara berkelompok (Johnson \& Johnson, 1994). Dari uraian di atas model kooperatif ini bertujuan untuk keberhasilan kelompok, karena dalam pelaksanaannya peserta didik diajak belajar secara berkelompok untuk mengerjakan tugas-tugas yang diberikan pendidik secar aktif bertukar pendapat dengan anggota kelompok.

\section{Manfaat Model Kooperatif}

Menurut Killen, $\mathrm{R}$ mengemukakan manfaat model kooperatif sebagai berikut:

a. Mengajarkan peserta didik untuk mengurangi ketergantungannya pada pendidik dan lebih percaya pada kemampuan diri mereka;

b. Mendorong peserta didik untuk mengungkapkan ide-ide secara verbal;

c. Membantu peserta didik untuk belajar bertanggung jawab dan belajar menerima perbedan;

d. Membantu peserta didik memperoleh hasil belajar yang baik, meningkatkan hubungan sosial, hubungan positif antar individu, 
ISSN 2548-9119

memperbaiki keterampilan dalam mengatur waktu;

e. Memetik banyak pelajaran dari kerja sama yang dibangun;

f. Peserta didik akan lebih banyak, menyukai sekolah, menyukai antarsesamanya;

g. Mempertinggi kemampuan peserta didik untuk menggunakan informasi dan keterangan pelajaran abstrak yang kemudian dapat diubah peserta didik menjadi suatu keputusan yang riil;

h. Menyediakan

beberapa kesempatan pada peserta didik untuk membandingkan jawaban dan mencocokkannya dengan jawaban yang benar.

\section{Langkah-Langkah Model Kooperatif}

Langkah-langkah model kooperatif. Seperti pada Tabel 1.1 di bawah ini.

Tabel 1.1 Langkah-langkah Model Pembelajaran Kooperatif

\begin{tabular}{|c|c|}
\hline Fase & Tingkah Laku Pendidik \\
\hline $\begin{array}{l}\text { Fase-1 } \\
\text { Menyampaikan tujuan dan } \\
\text { memotivasi peserta didik }\end{array}$ & $\begin{array}{l}\text { Pendidik menyajikan semua tujuan } \\
\text { pelajaran yang ingin dicapai pada } \\
\text { pelajaran tersebut dan memotivasi } \\
\text { peserta didik belajar. }\end{array}$ \\
\hline $\begin{array}{c}\text { Fase-2 } \\
\text { Menyajikan informasi }\end{array}$ & $\begin{array}{l}\text { Pendidik menyajikan informasi } \\
\text { kepada peserta didik dengan jalan } \\
\text { demonstrasi atau lewat bahan } \\
\text { bacaan. }\end{array}$ \\
\hline $\begin{array}{l}\text { Fase-3 } \\
\text { Mengorganisasikan peserta didik } \\
\text { ke dalam kelompok kooperatif }\end{array}$ & $\begin{array}{l}\text { Pendidik menjelaskan kepada } \\
\text { peserta didik bagaimana caranya } \\
\text { membentuk kelompok belajar dan } \\
\text { membantu setiap kelompok agar } \\
\text { melakukan transisi secara efisien. }\end{array}$ \\
\hline $\begin{array}{c}\text { Fase-4 } \\
\text { Membimbing kelompok bekerja } \\
\text { dan belajar }\end{array}$ & $\begin{array}{c}\text { Pendidik membimbing kelompok- } \\
\text { kelompok belajar pada saat mereka } \\
\text { mengerjakan tugas mereka. }\end{array}$ \\
\hline $\begin{array}{l}\text { Fase-5 } \\
\text { Evaluasi }\end{array}$ & $\begin{array}{l}\text { Pendidik mengevaluasi hasil belajar } \\
\text { tentang materi yang telah dipelajari } \\
\text { atau masing-masing kelompok } \\
\text { mempresentasikan hasil kerjanya. }\end{array}$ \\
\hline $\begin{array}{c}\text { Fase- } 6 \\
\text { Memberikan penghargaan }\end{array}$ & $\begin{array}{l}\text { Pendidik mencari cara-cara untuk } \\
\text { menghargai baik upaya maupun } \\
\text { hasil belajar individu dan kelompok. }\end{array}$ \\
\hline
\end{tabular}

(Ibrahim et al, 2000: 10) 


\section{Modul Mahasiswa (MM)}

Sujana (2004) menyatakan bahwa "modul merupakan satu unit program belajar-mengajar terkecil yang secara rinci yang memuat: tujuan instruksional yang akan dicapai, topik yang akan dijadikan dasar proses belajarmengajar, pokok-pokok materi yang dipelajari, kedudukan dan fungsi model dalam kesatuan program yang lebih luas, peranan pendidik dalam proses belajar-mengajar, alat-alat dan sumber yang akan dipergunakan, kegiatankegiatan belajar yang harus dilakukan dan dihayati secara berurutan, lembar kerja yang harus di isi oleh mahasiswa dan program evakuasi yang akan dilaksanakan". Jadi, modul mahasiswa merupakan lembaran yang berisi rencana tugas yang harus dikerjakan oleh mahasiswa. Tugas yang dimaksud adalah tugas sesuai dengan materi yang diajarkan.

\section{Pembelajaran IPA}

Peserta didik dalam pembelajaran IPA didorong untuk menemukan sendiri dan mentransformasikan informasi kompleks, mengecek informasi baru dengan aturan-aturan lama di dalam pikirannya, dan merevisinya apabila aturan-aturan ini tidak lagi sesuai. Pandangan dasar tentang pembelajaran adalah bahwa pengetahuan tidak dapat dipindahkan begitu saja dari pendidik ke peserta didik. Peserta didik harus didorong untuk mengonstruksi pengetahuan di dalam pikirannya, agar benar-benar memahami dan dapat menerapkan pengetahuan, peserta didik perlu didorong untuk bekerja memecahkan masalah, menemukan segala sesuatu untuk dirinya, dan bersusah payah dengan ide-idenya (Kemendikbud, 2013).
Pembelajaran IPA memiliki peran yang sangat penting dalam menghasilkan lulusan yang memiliki kemampuan dan karakter yang berkualitas. Dengan pembelajaran IPA dapat menumbuhkan kebiasaan berfikir secara ilmiah, sehingga mampu menghasilkan keterampilan memecahkan persoalan-persoalan dalam kehidupan sehari-hari.

\section{Model Kooperatif dengan Bantuan MM dalam Pembelajaran IPA di Program Studi S1 PGSD}

Pembelajaran IImu Pengetahuan Alam harus disajikan secara kontekstual, agar peserta didik mudah memahami konsep materi. Dalam materi IPA, mahasiswa juga dihadapkan pada latihan soal-soal atau pemecahan masalah. Dengan penerapan model kooperatif menjadi solusi bagi permasalahan tersebut, karena dalam memecahkan masalah bisa bekerja sama dengan temannya. Selain itu model kooperatif juga berdampak pada hubungan internal antar mahasiswa, dengan pembelajaran kelompok mahasiswa bisa saling bertukar informasi untuk meningkatkan prestasi.

Pembelajaran IPA di Perpendidikan Tinggi terdiri dari beberapa materi yang cakupannya luas, sebagai contoh materi Klasifikasi Makhluk Hidup. Pada materi Klasifikasi Makhluk Hidup yang dibahas tentang urutan takson, nama ilmiah, sistem kingdom (sistem dua kingdom, sistem tiga kingdom, sistem empat kingdom, sistem lima kingdom, dan sistem enam kingdom). Materi yang cakupannya luas harus disajikan dengan cara yang fleksibel agar semua tujuan pembelajaran tercapai, salah satu cara yang bisa digunakan yaitu dengan menggunakan model kooperatif dengan bantuan Modul Mahasiswa (MM). 
Pada penerapan model kooperatif dengan bantuan MM, memudahkan Dosen membimbing mahasiswa dalam kerja kelompok. Dengan adanya MM, mahasiswa dapat mengerjakan tugas dalam perkuliahan lebih terstruktur, sehingga materi yang cakupannya luas dapat terselesaikan dengan tuntas dan tepat waktu. Hal ini sesuai pendapat yang dikemukakan oleh Suyanto \& Asep Jihat (2002) bahwa salah satu ciri model kooperatif bertujuan untuk menuntaskan materi yang dipelajari.

\section{Kesimpulan}

Materi pembelajaran IImu Pengetahuan alam di Perguruan Tinggi cakupannya luas harus disajikan dengan cara yang fleksibel agar semua tujuan pembelajaran tercapai, salah satu cara yang bisa digunakan yaitu dengan menggunakan model kooperatif dengan bantuan Modul Mahasiswa (MM). Model kooperatif merupakan model pembelajaran yang mengutamakan kerja kelompok yang terdiri dari 4-6 anggota. Sedangkan modul mahasiswa merupakan lembaran yang berisi rencana tugas yang harus dikerjakan oleh mahasiswa.

Pada penerapan model kooperatif dengan bantuan MM, memudahkan Dosen membimbing mahasiswa dalam kerja kelompok. Dengan adanya MM, mahasiswa dapat mengerjakan tugas dalam perkuliahan lebih terstruktur, sehingga materi yang cakupannya luas dapat terselesaikan dengan tuntas dan tepat waktu.

\section{DAFTAR PUSTAKA}

Ibrahim et al. 2000. Pembelajaran Kooperatif. Surabaya: UNESA-University Press.

Isjoni. 2007. Cooperative Learning Efektifitas Pembelajaran Kelompok. Bandung: Alfabeta.

Johnson \& Johnson. 1994. Learning Together and Alone, Cooperative, Competitive, and Individualistic Learning. Boston: Allyn and Bacon.

Kardi, S. dan M. Nur. 2000. Pengajaran Langsung. Surabaya: University Press.

Kemendikbud. 2013. Buku Guru IImu Pengetahuan Alam. Jakarta: Kementrian Pendidikan dan Kebudayaan.

Killen, R. effective Teaching Strategies. Australia: Social Science Press.

Nana, S. 2004. Teknologi Pengajaran. Bandung: Sinar Baru Algensindo.

Suprijono, A. 2009. Cooperative Learning, Teori \& Aplikasi PAIKEM. Surabaya: Pustaka Pelajar.

Suyanto \& Asep Jihad. 2002. Menjadi Guru Profesional. Jakarta: Erlangga Group. 